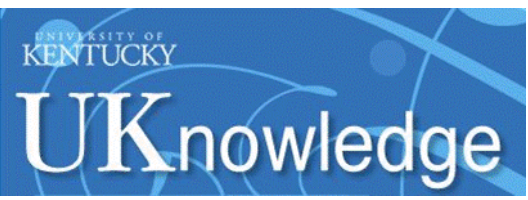

University of Kentucky

UKnowledge

7-2008

\title{
Medical Students: Abuse of Psychoactive Substances and Sexuality Aspects
}

\author{
Kepler Alencar Mendes Carvalho \\ Faculty of Medical Sciences Santa Casa, Brazil \\ Maria José Carvalho Sant'Anna \\ Faculty of Medical Sciences Santa Casa, Brazil \\ Verônica Coates \\ Faculty of Medical Sciences Santa Casa, Brazil \\ Hatim A. Omar \\ University of Kentucky, hatim.omar@uky.edu
}

Follow this and additional works at: https://uknowledge.uky.edu/pediatrics_facpub

Part of the Pediatrics Commons

Right click to open a feedback form in a new tab to let us know how this document benefits you.

\section{Repository Citation}

Carvalho, Kepler Alencar Mendes; Sant'Anna, Maria José Carvalho; Coates, Verônica; and Omar, Hatim A., "Medical Students: Abuse of Psychoactive Substances and Sexuality Aspects" (2008). Pediatrics Faculty Publications. 74.

https://uknowledge.uky.edu/pediatrics_facpub/74

This Article is brought to you for free and open access by the Pediatrics at UKnowledge. It has been accepted for inclusion in Pediatrics Faculty Publications by an authorized administrator of UKnowledge. For more information, please contact UKnowledge@lsv.uky.edu. 


\section{Medical Students: Abuse of Psychoactive Substances and Sexuality Aspects}

Digital Object Identifier (DOI)

http://dx.doi.org/10.1515/IJAMH.2008.20.3.321

\section{Notes/Citation Information}

Published in International Journal of Adolescent Medicine and Health, v. 20, no. 3, p. 321-328.

(C) Freund Publishing House Ltd.

The copyright holder has granted permission for posting the article here. 


\title{
Medical students: Abuse of psychoactive substances and sexuality aspects
}

\author{
Kepler Alencar Mendes Carvalho, $\mathrm{BA}^{1}$, Maria Jose Carvalho Sant'Anna, MD', \\ Veronica Coates, $\mathrm{MD}^{1}$ and Hatim A Omar, MD, FAAP ${ }^{2}$
}

'Adolescent Clinical Unit, Department of Pediatrics, Santa Casa of São Paulo Faculty of Medical Sciences, São Paulo, Brazil and ${ }^{2}$ Division of Adolescent Medicine, Department of Pediatrics, University of Kentucky, Lexington, USA

\begin{abstract}
University students aged 17 to 24 years of age are prone to many risk factors. Objectives: Identify risk factors related to exploring sexuality and characteristics of consumption of psychoactive substances in students attending medical school. Methods: 465 Medical students from Santa Casa of Såo Paulo Faculty of Medical Sciences (FCMSCSP) were prospectively and transversely evaluated during 2005. An anonymous, semi-structured, self-filling questionnaire was used. The average age of the students was 21.5 years, $43 \%$ females. $76.2 \%$ preferred alcohol, and $11.1 \%$ tobacco consumption; chloroethane (lança-perfume) consumption occurred in $22.6 \%$ and $15.3 \%$ consumption of other types of illicit drugs, with marijuana as the most used one (94\%). $70.3 \%$, of the parents drink alcohol and $30.5 \%$ smoke tobacco. As for the students' sexuality, $85.3 \%$ have already had sexual intercourses, starting at average age of $17.88 .8 \%$ used condom during the first sexual intercourse, however, $35.6 \%$ did not use it regularly; $5.4 \%$ had already had some type of DST. $79.8 \%$ of the females preferred having used contraceptive methods; however, $28.1 \%$ had a suspicion of pregnancy, which was confirmed in $7.9 \%$ of the cases. $9.9 \%$ of the students had ideas of abortion, $12.5 \%$ have effectively attempted it. $85 \%$ found medical school stressing and to relieve tension, $33.8 \%$ practiced sports; $6.9 \%$ preferred either licit or illicit drug consumption, and $5 \%$ used tranquilizers. The results showed risk behaviors: unsafe sex and the use of licit and illicit drugs indicated the need to establish guidance programs on reproductive health, improving self-esteem, and prevention during medical education.
\end{abstract}

Keywords: Medical students, medical education, psychoactive substance abuse, sexuality, Brazil

Correspondence: Hatim Omar, MD, FAAP, Professor of Pediatrics and Obstetrics/Gynecology, Chief, Adolescent Medicine and Young Parent programs, J422 Kentucky Clinic, University of Kentucky, Lexington, KY 40536 USA. Tel. 859-323-6426 ext. 311; Fax. 859-257-7706; E-mail: haomar2@uky.edu

Submitted: January 01, 2008. Revised: February 15, 2008. Accepted: February 18, 2008.

\section{INTRODUCTION}

Adolescence is characterized by rapid changes in biological, psychological, and social development, evidenced by the 'normal adolescence crisis' (1), which arises from the interaction of the individual with the environment (2-3). Most medical students are between 17 and 24 years of age, and going to college is a very important moment in their lives. From then on, their social insertion is widened and their working experiences are beginning, thus changing their professional identity, coupled with the larger identity process (4). The freshmen face new situations that give rise to feelings of joy and excitement, 
insecurity and anxiety leading to risky behaviors (5). Under that context, the use of psychoactive substance occurs, especially alcohol and tobacco, as well as the beginning of such risky sexual behavior as negligence to use contraceptive methods and prevention against sexually transmitted diseases (DST) (6).

The worry about detecting the use and the abuse of psychoactive substances, as well as attitudes in individuals who shall become health providers is certainly evident. This concern is based on the assumption that such uses and attitudes might lead to the probability of those students becoming addicted professionals with the use of alcohol and drugs, thus compromise their ability to perform an early diagnosis, to forward and/or to treat addicted patients. Additionally, the physician should work as a role model for his patients and other health professionals with whom they work (7), and so can provide humanistic assistance, without prejudice and disinformation.

Several factors that contribute to drug consumption by youngsters are common feelings of youth, such as omnipotence, magical thought, group influence, or high levels of social responsibility (8-9). According to the World Health Organization (WHO), five main factors lead to the abuse of psychoactive substances: (1) misinformation; (2) difficulty in family relationships, schoolm and/or the working environment; (3) lack of satisfaction with quality of life; (4) health problems, and (5) facility in the access to such substances (3). The prevention of damage is fundamental during adolescence and youth, with knowing the epidemiology of consumption of such substances being important to plan prevention strategies.

Regarding the exercise of sexuality, the youngster many times receives information from inexact sources; we live in a society full of eroticism, where students receive dubious messages about what is good or bad in relation to sexuality. Negligent social permissiveness exists, and usually sexual activity is started through the influence of their friends and society without enough knowledge about what is really desired. Sexual education has always been the parents' prerogative; yet, it is virtually inexistent in most families, either by lack of knowledge or the parents' own difficulty in dealing with any matter related to their children's sexuality. Youngsters are not satisfied with the guidance that the family and schools provide. In most schools, information is still provided in science or biology classes, giving preference to the physiological and anatomical aspects, not leaving room for discussions on sexuality or an open and honest dialogue on the youngsters' sexual anxieties and worries (2).

In this paper, we wanted to identify risk factors related to sexuality and the characteristics of the consumption of psychoactive substances by scholars attending medical school for the organization of preventive strategies.

\section{METHODS}

Medical students $(n=465)$ from the first to sixth year of Santa Casa of São Paulo Faculty of Medical Sciences (FCMSCSP) were prospectively and transversely evaluated from January to December, 2005. An anonymous, semi-structured, self-filling questionnaire was used, after the student's agreement, being instructed on the purpose of the study and after signing the informed consent form. The research was approved by the Ethics and Research Committee of the institution. Epi-info $6.04 \mathrm{~d}$ software with qui-square and mean tests was used for the analysis. 


\section{RESULTS}

In 2005, 600 students were enrolled in FCMSCSP, of which $465(77.5 \%)$ answered the questionnaire. The average age was $21.5 ; 43 \%$ were female and $57 \%$ were male; $63.6 \%$ reported a family income higher than 20 minimum wages, and $6.9 \%$ worked. $77.8 \%$ practiced physical activities, which was regular in $80 \%$ of the cases.

In relation to drugs, $76.2 \%$ preferred alcohol consumption, with a discrete variation during the program. The consumption frequency was $46.5 \%$ once a week, $33.5 \%$ once a month, and $2.0 \%$ daily; $54.4 \%$ tried it out of curiosity, $18.2 \%$ over the influence of friends. As for tobacco: $11.1 \%$ preferred using it, average of 6.4 cigarettes a day, beginning in $36 \%$ of the cases before 15 years of age, and in $26 \%$ of the cases between 16 and 17 . When we compared the use of alcohol and tobacco, we observed a statistical difference $(p<.05)$; alcohol was consumed more than tobacco, regardless of the period of the course.

"Lança-perfume" (chloroethane) consumption occurred in $22.6 \%$ of the students, once a month in $98 \%$ of the cases and "only in parties" in $44.2 \%$. Among the students interviewed, $15.3 \%$ used other illicit drugs, with rates that varied during the course periods. Among other drugs, marijuana was the most used ( $94 \%$ of the cases); $88.4 \%$ of them realized college mates used psychoactive substances, $74.6 \%$ preferred facility of access to such substances. Among marijuana users, $31.3 \%$ reported using it as a habit, $8.7 \%$ reported using it daily; $17.4 \%$ twice a week, $23.9 \%$ once a week, and $50 \%$ monthly. In relation to gender, there was a statistically significant difference $(p<.05)$ for the higher consumption of illicit drugs among men in relation to women.

When we evaluated the families of these youngsters, we found that $4.1 \%$ of them had used other types of drugs; marijuana was reported in $94.1 \%$ of the cases. In $73.8 \%$ of families alcohol use was reported, in $29.8 \%$ the father was the one that used it; $11.3 \%$ used it daily, and in $30.5 \%$ the parents used tobacco. Parents were married in $84.2 \%$ of the cases, and $95 \%$ had a good to optimum relationship; most youngsters evaluated (71.3\%) lived with their parents and got along well with them.

Regarding sexuality, $85.3 \%$ preferred active sexual life, with an average starting age at 17 years, and an average relationship stability period with the partner before the first intercourse of 9 months. $91 \%$ had only one current sex partner, $96 \%$ in the male gender and $88 \%$ in the female gender; $22.4 \%$ of the students (all male), had already had sexual intercourse for payment. $5.4 \%$ of the students were infected with some type of STD. In relation to birth control, $45.6 \%$ of the students preferred using emergency birth control, either by them or their sexual partner, with an average use of 2.2 times since the beginning of sexual activity. $83.7 \%$ of the students preferred regular use of a birth control method; $88.8 \%$ of the students used a condom in their first sexual intercourse, but $35.6 \%$ did not use it regularly, with a significant variation during the different periods of the course (see figure 1). We also found that male students used a condom more regularly than partners of the female students researched $(p<.05)$.

Pregnancy was suspected by $28.1 \%$ of the students and/or their partners, and it was confirmed in $7.9 \%$ of the cases. $9.9 \%$ of the students referred to the idea of abortion, with variation in rates according to course period, of which, $12.5 \%$ had accomplished it. When we compared suspicion of pregnancy between the three first periods of the course with the three last ones, we did not find statistically significant differences $(p=0.1)$. However, when the comparison performed 


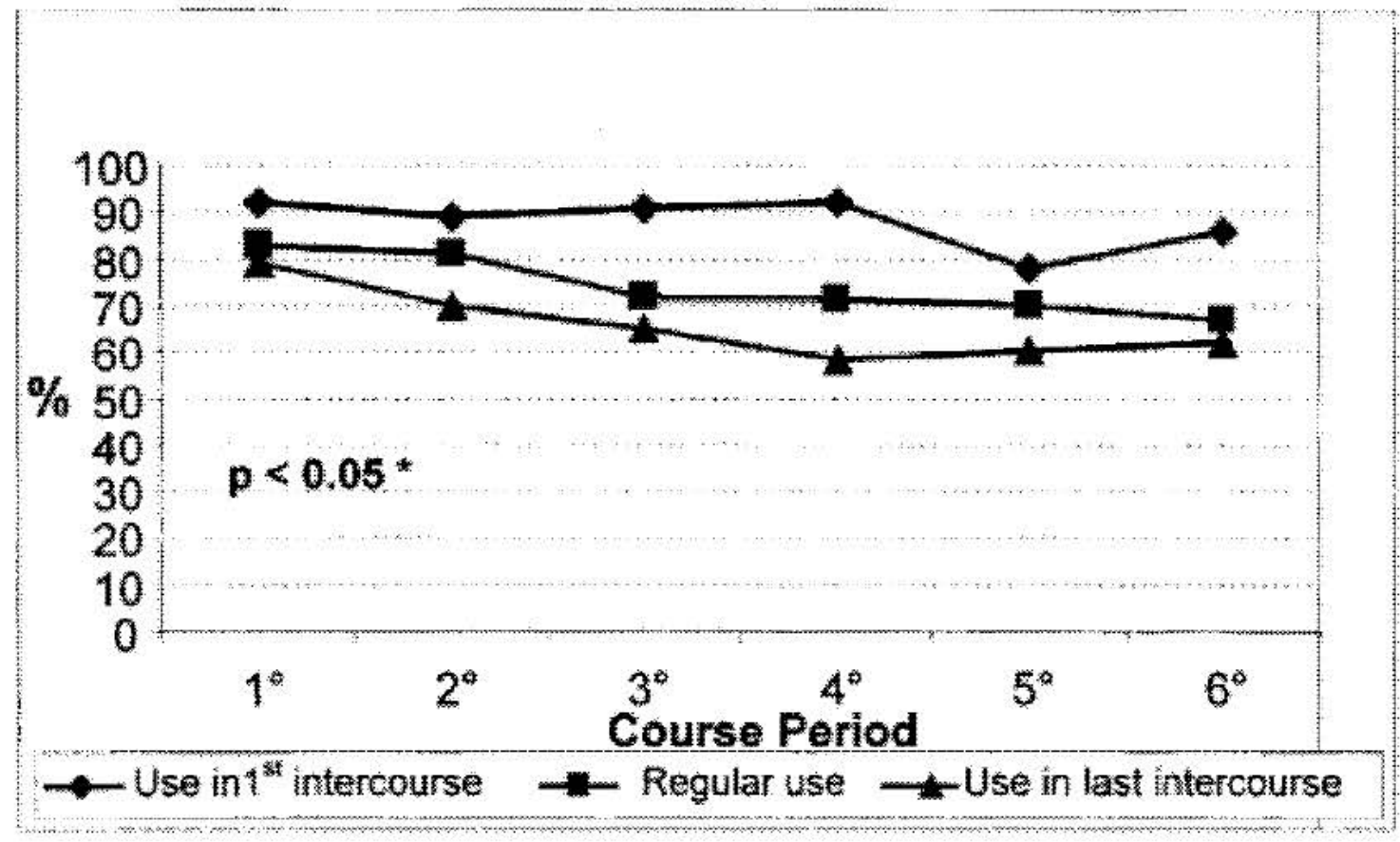

* p value for the Qui-square test

Fig. 1: Use of condom by FCMSCSP Medicine students, according to course period

for the same groups was in relation to the idea of abortion, there was a statistically significant difference $(\mathrm{p}<0.05$ ): a higher idea of abortion for the last periods of the course.

From the students interviewed, $85 \%$ considered the schedule of the course to be stressing; to relieve tension, $33.8 \%$ practiced sports; $38.4 \%$ went out with friends; $6.9 \%$ used either licit or illicit drugs; $16.7 \%$ preferred to be with family, and $5 \%$ used tranquilizers, of which $27.8 \%$ used them once a week, and $72.2 \%$ sporadically.

\section{DISCUSSION}

According to The Pan American Health Organization (PAHO), youth is the period between 15 to 24 years of age, a time when youngsters must assume an adult role, with all its responsibilities and rights, but still characterized by uncertainties and crises due to the new roles and challenges (3). The average age of students evaluated was 21.5 years of age, still considered within the youth or late adolescence range. Youth is often a period of great risk, due to insecurity and anxiety, which frequently lead to risk behaviors like the use of psychoactive substances or risky sexual behavior.

\section{Family}

Most youngsters evaluated come from structured families, with married parents and good family relationships. The influence of the family on the sexual behavior of the youngsters was analyzed from several aspects, once the family context is directly related to the time when the sexual activity begins. A protective factor against an early start in sexual life is in structured and present families, according to Markham et al (10). We observed an average sexual initiation at 17 years of age, which can be considered a late start when compared with 
UNESCO's 2001 research, where we find that in Brazil, youngsters start their sexual life much earlier, males between 13.9 and 14.5 , and female between 15.2 and 16 years of age (11).

Usually youngsters start their sex life without appropriate protection, and despite the finding in our study that most students used a condom in their first sexual intercourse, we found high rates of regular non-use. Thus, we interpreted that using a condom is not only limited to information but also by the meaning the affective relationship bears. The youngster frequently adopts a magic thought on the risks related to living sexuality, not establishing in a conscious manner the link of the sexual activity with vulnerability and the need for protection (8). In general, they are aware of the existence of preventive methods, but are resistant to their utilization due to the fear that they might impair his/her health, or for not knowing how to use it correctly, the difficulty obtaining them, or even for a conscious or unconscious desire for pregnancy $(1,8)$. We found that $20.2 \%$ of the youngsters studied do not use birth control methods; $35.6 \%$ did not use a condom regularly despite a good educational level, which should theoretically reflect a larger knowledge on preventive health care.

Interestingly, the use of a condom was higher in the first graduation year, being gradually reduced throughout the course. We believe that despite obtaining a better knowledge, the increase in non-usage might be due to the greater rate of youngsters with a stable relationship; dating a single partner, showing they value affective relationships. Interestingly, we noticed that most of them $(62.84 \%)$ began their sexual relations with their partners after an average dating period of 9 months. That rate is even higher if we consider the female gender only ( $89 \%$ ). Data from the GRAVAD research, 2002, performed in three large Brazilian capitals among adolescents and youngsters from both genders with ages between 18 and 24 years indicated that most adolescents that became pregnant $(97.5 \%)$ and adolescents who already made a girlfriend pregnant $(85.8 \%)$ were found in stable relationship contexts (12). Before the diversity of contexts in which unprotected sexual activity might occur, a distinguished and attentive look should be acknowledged, free from prejudice and individualized for each youngster.

Pregnancy suspicion and idea of abortion Despite its being illegal in Brazil, abortion seems to be a widespread idea amongst youngsters. According to data from the Health Department, induced abortion is the fifth greatest cause of hospital admission amongst teens, and the third cause for maternal deaths in Brazil: $16 \%$ among $15-$ 24 years old women in the poorest areas (13-14). We observed that $28.1 \%$ of the youngsters evaluated presented suspicion of pregnancy, which was confirmed in $7.9 \%$. Among them, $9.9 \%$ thought about the possibility of abortion, and $12.5 \%$ had effectively done so, rates not so different from those found by Souza et al (15)$15.3 \%$ in university female students. The high abortion frequency might result from the deals between couples as for assuming the pregnancy/child; university youngsters thought it was more tolerable to correct an unplanned pregnancy with abortion because in the higher layers of society, abortion can be performed in more acceptable medical conditions, despite being embarrassing, clandestine, and expensive (15).

\section{Use of psychoactive substances}

A few studies have been conducted on licit and illicit drug consumption by university students in Brazil, especially by medical 
students, which justify the research. The $5^{\text {th }}$ Survey (2004) performed by the Brazilian Information Center on Psychotropic Drugs, showed that the age for the first consumption of legal drugs, alcohol, and tobacco was earlier than the use of other drugs researched-usually 12 years and 5 months for alcohol and 12 years and 8 months for tobacco. As for abusive and non-prescription medication use, on average, the first usage occurred at 13 years. The same study shows that good relationships with parents and their children and religion seem to be protective factors against the heavy use of alcohol and other drugs (16). The knowledge of protective and risk factors is fundamental for adolescents and youngsters to prevent the use of drugs. In our sample, we found a high rate of alcohol consumption (76.2\%), similar to that found by Andrade et al (17) in a study evaluating medical colleges from São Paulo state.

We have come across $46.5 \%$ weekly alcohol consumption, with a high incidence amongst relatives, showing wide social acceptance; most tried out of curiosity and earlier than they should have. Parents usually worry about illicit drugs and forget about alcohol, a finding that must be taken into consideration in preventive proposals. Tobacco consumption presented rates of $11.1 \%$, frequently with an early start, between 11 and 15 years of age. Despite being precocious, such indexes might be considered low if we consider the $5^{\text {th }}$ CEBRID Survey, 2004 that found $26.2 \%$ in São Paulo. When comparing our sample with data from Andrade et al (17), we see that tobacco consumption among Medical scholars is currently smaller, which is statistically significant $(p<.05)$, and that the reduction may be due to an anti-smoking campaigns performed during the last years.

During the 6 years of the course, an increase was observed in the predominance of tobacco and alcohol use, rates also found by Brooke et al (18). Such increases might be related to personal factors as well as to factors related to the Medical course and professional stress. The course exposes the individual to stressful conditions, especially during the last years, when its activities are almost entirely practical, with an intense work load, double duties, the need to deal with decision-making situations that concern life and death, often accompanied by the insecurity of their knowledge and the competitiveness among the students themselves. We found that going out with friends and going to bars is a way of leisure and lessening tension.

Frequent alcohol usage as a mitigating factor for tension, the need to share behaviors with peers, the belief that alcoholic beverage ingestion is a riskless factor, and usually the easy access to other psychoactive substances are factors that might explain the greater probability of using alcohol and other drugs from that group. It is important to highlight that going to bars and using alcohol are socially accepted and stimulated practices in Brazil. When we analyze the use of tranquilizers among the evaluated scholars, we find compatible rates $(5 \%)$ to those found by Andrade et al (17) in other medical colleges in the State of São Paulo.

We found similar values in all graduation periods, as opposed to Silva et al (19), Mesquita et al (20), Andrade et al (17) and Kerr-Correa et al (7), who observed a larger use of tranquilizers among students from last year in relation to the first years of course $(7,17,19-20)$. Kerr-Correa et al (7) questioned whether this finding is due to the end of the course stress, duty overload, and proximity of the internship examination. Besides, obtaining prescriptions and medications from the hospital by medical students it becomes easier with time. 


\section{CONCLUSIONS}

The results obtained here suggest several risk behaviors in the youngsters evaluated: unprotected sexual life and the use of licit and illicit drugs. The results indicate the need for new research of the same nature to establish guidance programs on reproductive health, with improvement of selfesteem and drug use prevention during academic education. We suggest an increase of research in graduation class periods, including aspects related to sexuality and the use of psychoactive substances, as well as other related problems. We believe it is possible to help students to position themselves as responsible in guiding their sexuality and professional future.

\section{ACKNOWLEDGMENTS}

The authors thank CNPq - Conselho Nacional de Desenvolvimento Científico e Tecnológico - "National Counsel of Technological and Scientific Development" for their generous financial support of this work. We are grateful to the Support Center for Scientific Publications of Santa Casa de Săo Paulo Faculty of Medical Sciences for the editorial assistance.

\section{REFERENCES}

1. Coates V. Repercussðes da Adolescencia no Âmbito Familiar. In: Medicina do Adolescente. IN: Coates V, Beznos GW, Françoso LA, eds. São Paulo: Sarvier, 2003:609-15.

2. Saito MI. Adolescéncia, Cultura, Vulnerabilidade e Risco. A Prevençẵo em Questăo. In: Saito MI, Silva LEV, eds. Adolescencia - Prevençăo e Risco. São Paulo: Atheneu, 2001:33-8.

3. Organizacion Panamericana de la Salud. Recomendaciones para la atencion integral de salud delos adolescentes com ènfesis en salud sexual y reproductivas, 2000.

4. Ministério da Saúde. Secretaria de Politicas de Saude. Área de Saúde do Adolescente e do Jovem. Saude e desenvolvimento da juventude brasileira: construindo uma agenda nacional. Brasilia: DF, 2000.

5. Hadlich C, Keller JA, Bacellar R, Santos RN, Silva RSP, Guimarães RGM, et al. Recepção comunicativa aos calouros de medicina/2000: Um caminho para a participação na universidade. Rio de Janeiro, 2000. Available at: http://www.saudebrasil net.com.br/premios/saude/premio3/tra balhos/066.pdf. Accessed $18 \mathrm{Dec}$ 2007.

6. Akvardar Y, Demiral Y, Ergor G, Ergor A, Bilici M. Akil OO. Substance use in a sample of Turkish medical students. Drug Alcohol Depend 2003;72:117-21.

7. Kerr-Correa F, Andrade AG, Bassit AZ, Boccuto NMVF. Uso de álcool e drogas por estudantes de medicina da Unesp. Rev Bras Psiquiatr 1999;21: 95-100.

8. Sant'Anna MJ, Catunda JK, Carvalho KA, Coates, V, Omar HA. Pregnant teenager involvement in sexual activity and the social context. Scientific WorldJournal 2006;6:998-1007.

9. Feres AD, Rezende DF, Botelho FH, Câmara FG, Martins GA. O uso de preservativo pelos alunos da Faculdade de Medicina de Barbacena, em uma abordagem sociocultural a respeito da AIDS/The use of condom by the students of Medical College of Barba. cena-a social cultural approach related to AIDS. DST $\mathbf{J}$ Bras Doenças Sex Transm 2006;13:31-5.

10. $\mathrm{M}$ arkham $\mathrm{CM}$, Tortolero SR, EscobarChaves SL, Parcel GS, Harrist R, Addy RC. Family connectedness and 
sexual risk-taking among urban youth attending alternative high schools. Perspect Sex Reprod Health 2003; 35:174-9.

11. UNESCO. Aids: $O$ que pensam os jovens? Políticas e Praticas Educativas. Brasília. UNESCO-UNAIDS, (Cadernos UNESCO Brasil - Série educação para a saúde, 1), 2002.

12. Bozon M. As características da população pesquisada/Characteristics of the population researched. In: Heilborn ML, Aquino EML, Bozon $M$, Knauth DR. O aprendizado da sexualidade: reprodução e trajetórias sociais de jovens brasileiros. Rio de Janeiro: Fiocruz, 2006:137-54.

13. Castro MG, Abramovay M, Silva LB. A iniciação sexual dos jovens. In: Juventudes e sexualidade. Brasil: UNESCO, 2004:67-73.

14. Mini stério da Saude. SecretariaExecutiva. Departamento de Informação e Informática do SUS. Indicadores e dados básicos (IDB2003) Brasília: Brasil, 2003.

15. Souza e Silva R. Especulaçðes sobre - papel do aborto provocado no comportamento reprodutivo das jovens brasileiras. Revista Brasileira de Estudos Populacionais, 19, n. 2. Available at: http://www.abep.nepo. unicamp.br/docs/rev_inf/vol19_n2_20 02/vol19 n2_2002_14artigo p249a26 2.pdf, Accessed 20 Nov 2007.

16. Carlini EA, Galduróz JCF, Noto AR. V Levantamento Nacional sobre o Consumo de Drogas Psicotrópicas entre studantes do Ensino Fundamental e Médio nas 27 Capitais Brasileiras, 2004. CEBRID (Centro Brasileiro de Informaçð̃es sobre Drogas Psicotróp-icas) UNIFESP, 2004. Available at: http://www. unifesp.br/dpsicobio/cebrid/levantame nto brasil2. Accessed 01 Dec 2007.

17. A ndrade AG, Bassit AZ, Kerr-Correa F, Tonhon AA, Boscovitz EZ, Cabral $M$, et al. Fatores de risco associados ao uso de álcool e drogas na vida, entre estudantes de Medicina do Estado de São Paulo. Rev ABPAPAL 1997;19:117-26.

18. Brooke D, Edwards G, Andrews T. Doctors and substance misuse: types of doctors, types of problems. Addiction 1993;88:655-63.

19. Silva LV, Malbergier A, Stempliuk, VA, de Andrade AG. [Factors associated with drug and alcohol use among university students]. Rev Saüde Püblica 2006;40:280-8.

20. Mesquita AM, de Andrade AG, Anthony JC. Use of the inhalant lanca by Brazilian medical students. Subst Use Misuse 1998;33:1667-80. 